\title{
Drying of Food Materials by Microwave Energy - A Review
}

\author{
B. C. Khodifad ${ }^{*}$ and N. K. Dhamsaniya ${ }^{2}$ \\ ${ }^{1}$ Department of Processing and Food Engineering, College of Agricultural Engineering and \\ Technology, Junagadh Agricultural University, Junagadh, Gujarat, India-362001 \\ ${ }^{2}$ Polytechnic in Agro-Processing, Junagadh Agricultural University, \\ Junagadh, Gujarat, India-362001 \\ *Corresponding author
}

\section{A B S T R A C T}

\section{Keywords}

Microwave energy, Drying, Microwave power, Hot air drying, Vacuum drying

Article Info

Accepted:

15 April 2020

Available Online:

10 May 2020
Microwave energy has very successful application in the field of food processing particularly for food drying to preserve the quality of the precious food materials. In this article, various food materials dried using microwave energy were extensively reviewed. Microwave drying appears to be a viable drying method for the rapid drying of food materials. It was noticed that at the higher microwave output power considerably lower drying time took place. The application of pulsed microwave energy was found more efficient than the continuous application. The microwave-vacuum drying could reduce drying time of vegetable leaves by around $80-90 \%$, compared with the hot air drying. Microwave drying maintained a good green colour close to that of the original fresh green leaves with surface sterilisation in most of the vegetables. The microwave heating of vegetable seed reduces the moisture content and anti-nutritional factor with maintaining the natural colour of the valuable seed.

\section{Introduction}

Drying is the oldest and traditional methods of food preservation and is the most widely used technique of preservation, which converts the food into light weight, easily transportable and storable product (Woodruff and Luh, 1986; Chauhan and Sharma, 1993). Although the origin of drying goes back to antiquity, there is a constant interest and technological improvements in the process of drying keeping this mode of preservation still as new. The specific objective of drying is to remove moisture as quickly as possible at a temperature that does not seriously affect the quality of the food. Drying can be accomplished by a number of traditional and advanced techniques. 
Sun drying is the conventional method where transfer of thermal energy from the product surface towards their centre is slow. Moreover, sun drying cannot be employed all throughout the year and at all places. Shade drying though maintains better quality takes many days to dry to constant weight. Inclusions to this list of traditional methods are spray drying, fluidized bed, kiln and cabinet drying.

Cabinet drying employs removal of moisture by flowing hot air under the controlled conditions of temperature, relative humidity and constant air flow. Fluid materials are generally being dried on a tray, drum or moving belt and spray drying (Hertzendorf $e t$ al., 1970). These methods readily offer themselves to conductive heat transfer and restricted to air convection and problem associated are colour change, protein denaturisation and poor rehydration quality. Freeze drying of liquid product yields excellent product quality with restricted use due to higher operation and set up costs (Sangamithra et al., 2014).While microwave drying is achieved by water vapour pressure difference between interior and surface regions which provides a driving force for moisture transport. Electromagnetic wave generated by the magnetron helps in heat transfer and, thus, moisture removal from the centre of food to the surface, therefore, drying the product in shorter time with higher yields and better quality (Srilakshmi, 2006).

Microwave heat treatment has many advantages compared to conventional methods. It is still not used widely for commercial purposes, which may be due to both technical and cost factors. The quality of microwave-treated products is better than that of conventional drying. However, higher equipment costs limit the use of microwave heating. Equipment costs can be reduced with time and developing the cost-effective technology. A major improvement in the efficiency of the treatment could change the economics of the microwave process. Thus, microwave heat treatment does appear to have a high potential for the processing of agricultural products in the near future (Vadivambal and Jayas, 2007).

\section{Principle of microwave heating}

Microwave heating is based on the transformation of alternating electromagnetic field energy into thermal energy by affecting the polar molecules of a material. Many molecules in food (such as water and fat) are electric dipoles, meaning that they have a positive charge at one end and a negative charge at the other, and therefore, they rotate as they try to align themselves with the alternating electric field induced by the microwave rays. The rapid movement of the bipolar molecules creates friction and results in heat dissipation in the material exposed to the microwave radiation. Microwave heating is most efficient on water (liquid) and much less on fats and sugars which have less molecular dipole moment (Sutar and Prasad, 2008).

Microwave heating uses electrical energy in the frequency range of $300 \mathrm{MHz}$ to $300 \mathrm{GHz}$ (Fig. 1), with $2450 \mathrm{MHz}$ being the most commonly used frequency. Microwaves are generated inside an oven by stepping up the alternating current from domestic power lines at a frequency of $50 \mathrm{~Hz}$ up to $2450 \mathrm{MHz}$. A device called the magnetron accomplishes this (Orsat et al., 2005). The polar molecules of food materials subjected to microwave radiation at $2450 \mathrm{MHz}$ will rotate $2.45 \times 10^{9}$ times per second. The frictions between fast rotating molecules generate heat throughout the food materials. The power generated in a material is proportional to the frequency of the source, the dielectric loss of the material, and the square of the field strength within it. 
The conversion of microwave energy (energy absorption) to heat is expressed by the following equation given by Linn and Moller (2003):

$$
P=2 \pi E^{2} f \varepsilon^{\prime \prime} \varepsilon_{0} V
$$

Where $\mathrm{P}$ is power, $\mathrm{W} ; E$ is the electric field strength, $\mathrm{V} / \mathrm{m} ; f$ is the frequency, $\mathrm{Hz} ;{ }^{\varepsilon_{0}}$ is the permittivity of free space $\left(8.854188 \times 10^{-}\right.$ $\left.{ }^{12} \mathrm{~F} / \mathrm{m}\right) ; \varepsilon^{\prime \prime}$ is the dielectric loss factor and $V$ is volume of the material, $\mathrm{m}^{3}$.

Dielectric properties of food depend on composition, temperature, bulk density and microwave frequency. Since the influence of a dielectric depends on the amount of mass interacting with the electromagnetic fields, the mass per unit volume or density will also have an effect on the dielectric properties. Table 1 shows the dielectric properties of food materials when subjected to microwave heating. It is important to note that dielectric properties are specific only for a given frequency and material's properties. The dielectric properties change with change in moisture and temperature, hence the uniformity of moisture and drying temperature govern the uniformity of the drying process (Venkatesh and Raghavan, 2004). Uniformity of drying is made possible with control of the duty cycle and power density. During microwave heating, the water present in the centre of the sample gets heated more readily than the samples at the edges, resulting in the inverse temperature profile (Lombrana et al., 2010).

\section{Microwave heating equipment}

Figure 2 shows a typical laboratory scale microwave oven which is used in different drying experiment (Vollmer, 2004). Microwaves are generated in a magnetron which feeds via a wave guide into the drying chamber. This cuboid cavity has metallic walls and so acts as a Faraday cage. The front door, made of glass, and the light bulb cavity are both covered by metal grids. The holes in the grids are small compared with the wavelength of the microwaves, hence the grids act just like metal plates.

Microwave drying requires a smaller floor space compared to conventional driers because the increase in processing rate makes it possible to design more compact equipment and hence plant capacity can be increased without additional building space. For instance, bread baking can be accomplished in $50 \%$ less time when microwave energy is used (Mullin, 1995). In microwave drying, operational cost is lower because energy is not consumed in heating the walls of the apparatus or the environment (Mullin, 1995; Thuery, 1992).

\section{Drying of food materials by application of microwave energy}

In drying of food materials, the aim is to eliminate moisture from food materials without affecting their physical and chemical structure. It is also important to preserve the food products and increase their storage stability which can be accomplished by drying. Microwave drying is a newer addition to the family of dehydration methods.

The mechanism for drying with microwave energy is quite different from that of ordinary drying. In conventional drying, moisture is initially flashed off from the surface and the remaining water diffuses slowly to the surface. Whereas, in microwave drying, heat is generated directly in the interior of material creating a higher heat transfer and thus a much faster temperature rise than in conventional heating. In microwave system, mass transfer is primarily due to the total pressure gradient established because of the rapid vapour generation within the material (Schiffmann, 2006). 
For drying of high moisture fruits and vegetables, a reduction in moisture content is time consuming especially in the final stage of drying. Microwave assisted drying as the final stage of air drying overcomes these disadvantages with high thermal efficiency (Chandrasekaran et al., 2013).The annular microwave dryer can be used for drying fresh honeysuckle and can realize continuous production, improved production efficiency and clean. A parabolic waveguide is used in microwave dryer, microwave distribution is more uniform in dryer (Geng and Ge, 2014).

Microwave assisted air drying is one of the methods where hot air drying is combined with microwave heating in order to enhance the drying rate. Microwave heating can be combined with hot air in different stages of the drying process. At the initial stage, microwave heating is applied at the beginning of the dehydration process, in which the interior gets heated rapidly. This creates a porous structure called 'puffing' which can further facilitate the mass transfer of water vapour. At the reduced drying rate period or at the final stage of drying, the drying rate begins to fall where the moisture is present at the centre and with the help of microwave heating, vapour is forced outside in order to remove bound water (Zhang et al., 2006).During vacuum drying, high energy water molecules diffuse to the surface and evaporate due to low pressure. Because of this, watervapour concentrates at the surface and the low pressure causes the boiling point of water to be reduced. Thus vacuum drying prevents oxidation due to the absence of air, and thereby maintains the colour, texture and flavour of the dried products (Chandrasekaran et al., 2013).

\section{Vegetables and spices}

Cui et al., (2003) dried garlic slice with combination of microwave-vacuum drying until the moisture content reached $10 \%$ (wet basis) and conventional hot-air drying at $45^{\circ} \mathrm{C}$ to final moisture content less than $50 \%$ (wet basis). Based on the experimental results they reported that the flavour or pungency, colour, texture, rehydration ratio and the quality of dried garlic slices were close to that of freezedried product and much better than that dehydrated by conventional hot-air drying. They suggested that the microwave-vacuum with air drying is a better way for drying garlic slices and other vegetables. They also noted that the microwave-vacuum drying resulted in acceleration of the drying rate and water evaporation at a lower temperature in the early stage of drying, however in the later stage (moisture content less than 10\% wet basis) air-drying at $45^{\circ} \mathrm{C}$ has a feasible alternative way to avoid hot-spots and product damage.

The power output of magnetron should be decreased with the reduction in moisture content in microwave-vacuum drying. Giri et al., (2014) evaluated microwave-vacuum drying characteristics of button mushroom (Agaricus bisporous) in a commercially available microwave oven with modification of drying system by incorporating a vacuum chamber. The effects of drying parameters, namely microwave power, system pressure, product thickness on the energy utilization and drying efficiency were investigated. The drying system was operated in the microwave power range of 115 to $285 \mathrm{~W}$, pressure range of 6.5 to $23.5 \mathrm{kPa}$ having mushroom slices of 6 to $14 \mathrm{~mm}$ thickness. They found that the drying efficiency values were decreases with decreasing moisture content, whereas, drying performance values were increased initially and remain constant up to a certain moisture level, than there after decreases as moisture content decreases during drying. Microwave power and slice thickness had significant effect on drying efficiency, whereas the system pressure observed less significant. 
They also noted that the microwave power had a negative effect on drying efficiency, thus decreases the drying efficiency as increases the microwave power. At a particular pressure level, the effect of slice thickness has more pronounced at lower microwave power levels. Soysal et al., (2009) experimented on intermittent and continuous microwave-convective air drying of potato.

The effectiveness of various microwaveconvective air-drying treatments was compared to establish the most favourable drying condition for potato in terms of drying time, energy consumption and dried product quality. The microwave-convective drying treatments were done in the intermittent and continuous modes at $697.87 \mathrm{~W}$ output power. Result shows that both the continuous and intermittent microwave-convective air drying gave good quality product compared to convective air drying.

In terms of drying time, energy consumption and dried product quality, the combination of intermittent-convective air drying with pulse ratio of 2.0 and $55^{\circ} \mathrm{C}$ drying air temperature was determined as the most favourable drying method for potato. They also reported that the drying technique provided considerable savings in drying time and energy consumption when compared to convective air drying and could be successfully used to produce dried potato without quality loss. Laguerre et al., (1999) carried out comparative study on hot air and microwave drying of onion. They dried onion in pilot scale hot air dryer and compared with onion dried in microwave tunnel. The result revealed that the minimum drying time and maximum drying rate were observed in microwave dried onion. The drying was influenced by air temperature and variety for hot air drying and microwave power and product shape for microwave drying. Akal and Kahveci (2016) investigated microwave drying characteristics of carrot slices. Microwave drying was carried out with drying thickness (1 and $2 \mathrm{~cm}$ ) and power levels (350, 460, and 600W). They observed that the drying rate increases as the drying thickness decreases and microwave power increases. The drying time reduced nearly fifty percent as microwave power increase from 350 to $600 \mathrm{~W}$. They also suggested that the microwave drying behaviour of carrot slice can be defined by semi-empirical page model.

Hu et al., (2007) investigated on microwavevacuum of edamame in a deep bed and compared in terms of drying rate, final moisture content and quality of dried products among the different heights of edamame in a deep bed. The results shows that there was a moisture gradient from the top to the bottom of the bed during the vacuum-microwave drying processing and the larger moisture gradient observed at the greater depth of the bed. Therefore, it can affect the uniformity and the quality of dried products. Applying high vacuum tends to improve the evaporation and volatilization of water from the material, whereas it may lead to electrical arcing which might result in the overheating of the product. The optimal drying conditions of edamame has given as for hot air drying at $70^{\circ} \mathrm{C}$ for $20 \mathrm{~min}$ and for vacuum microwave drying at a power intensity of $9.33 \mathrm{~W} / \mathrm{g}$ and at a vacuum pressure of $95 \mathrm{kPa}$ (gauge pressure) for $15 \mathrm{~min}$. Süfer et al., (2018) evaluated the textural profile of onion slices of 3 and $7 \mathrm{~mm}$ thicknesses undergoing convective drying $\left(50,60\right.$, and $\left.70^{\circ} \mathrm{C}\right)$ and microwave drying (68, 204 , and $340 \mathrm{~W}$ ) techniques with or without pre-treatment (dipping into brine solution (8\% $\mathrm{NaCl})$ ). The texture profile analysis was done at $25 \%$ compression and hardness, chewiness, springiness and gumminess values of onions were measured. They concluded that the temperature (convective) or power level (microwave) increased, the hardness and 
chewiness levels of dried onion slices were enhanced. Also noted that the values of measured parameters were higher in response to microwave application compared to convective drying. Bouraoui et al., (1994) dried potato slices using microwave drying, combined microwave plus convective drying and convective drying. Microwave drying has a potential for producing better quality dried products with significantly reducing drying duration from $10 \mathrm{~h}$ to $10 \mathrm{~min}$. They observed that the diffusivity increase with increasing internal temperature but to decrease (in microwave drying) with increasing moisture content. Sharma and Prasad (2001) conducted a study to explore the possibility of drying garlic cloves by combined hot air-microwave and hot air drying alone. The drying with 100 g sample sizes at temperatures of $40^{\circ} \mathrm{C}, 50^{\circ} \mathrm{C}$, $60^{\circ} \mathrm{C}$ and $70^{\circ} \mathrm{C}$ at air velocities of 1.0 and 2.0 $\mathrm{m} / \mathrm{s}$, using continuous microwave power of 40 $\mathrm{W}$ were carried.

The total drying time, colour and flavour strength of dried garlic cloves were used to evaluate the performance of the combined microwave-hot air drying and the conventional hot air drying processes. The volatile components found more in hot air microwave drying with respect to hot air drying and the flavour strength of garlic dried by hot air and microwave drying is 3.27 and $4.06 \mathrm{mg} / \mathrm{g}$ dry matter respectively. The drying time drops by $80-90 \%$ in hot air microwave drying with comparison to conventional hot air drying with a superior final product quality. Prabhanjan et al., (1995) evaluated dehydration characteristics of carrot cubes in a domestic microwave oven $(600 \quad \mathrm{~W})$ modified to allow passage of air at constant flow rate and a given air temperature. The parameters included inlet air at two temperatures $\left(45\right.$ and $60^{\circ} \mathrm{C}$ ) and microwave oven operation at two power levels (20 and $40 \%)$. They reported that in microwave drying substantial decrease $(25-90 \%)$ in the drying time and the product quality has better when dried at the lower power level and the colour of rehydrated carrots dried at power level 0 and $20 \%$ were better than at power level $40 \%$ and higher power levels resulted in product charring. Khraisheh et al., (2001) evaluated the quality and structural changes in potatoes during microwave and convective drying. A modified microwave oven was operated in either the microwave or convective drying mode to dry the samples. Ascorbic acid is an important indicator of quality and its selection was due to its heat labile nature. They found that the deterioration of ascorbic acid demonstrated first-order kinetic behaviour and it's depending on air temperature, microwave power and moisture content. Further they noted that the decreases vitamin $\mathrm{C}$ destruction has found in the microwave dried samples. The volumetric shrinkage of the samples exhibited a linear relation with moisture content.

The samples exhibited uniform shrinkage throughout convective processing whereas in microwave drying two shrinkage periods were observed. Microwave dried samples had higher rehydration potential. Starch gelatinisation was observed at high power levels and this reduced the degree of rehydration. Lin et al., (1998) studied the effects of vacuum microwave drying on the physical properties, nutritional values and sensory qualities of carrot slices and compared with conventional hot air drying. While testing the samples for retention of carotenes and vitamin $C$ they found that the air drying caused a decrease in both $\alpha$-and $\beta$ carotene content whereas less depletion of acarotene occurred with microwave-vacuum drying. The total loss of $\alpha$-and $\beta$-carotene during the drying was $19.2 \%$ for air-dried samples and $3.2 \%$ for vacuum-microwave dried samples. During air drying only $38 \%$ of vitamin $\mathrm{C}$ was retained whereas in 
microwave-vacuum drying $79 \%$ of vitamin C was retained. Vacuum microwave dried carrot slices had higher rehydration potential, higher $\alpha$-carotene and vitamin $\mathrm{C}$ content, lower density and softer texture than those prepared by air drying. Air dried carrot slices were darker and had less red and yellow hues. They also observed less colour deterioration occurred when vacuum-microwave drying was applied. Although freeze drying of carrot slices yielded a product with improved rehydration potential, appearance and nutrient retention. The microwave-vacuum drying carrot slices were rated as equal to or better than freeze dried samples by a sensory panel for colour, texture, flavour and overall preference in both the dry and rehydrated state. Ren and Chen (1998) dried American ginseng roots with hot air and combined microwave-hot air methods in a modified experimental microwave oven. They fix the hot air drying, the loading size, drying temperature and air flow rate were $100 \mathrm{~g}$, $40^{\circ} \mathrm{C}$ and $60 \mathrm{l} / \mathrm{min}$, respectively and for combined microwave hot air drying, the additional microwave power of $60 \mathrm{~W}$ was used. Combined microwave-hot air drying resulted in a substantial decrease (28.7$55.2 \%$ ) in the drying time and had little influence on the colour of the final product as compared to hot air drying.

Good quality of mushroom obtained at low pressure and moderate microwave heating $(120 \mathrm{~W})$ with higher drying rate by Lombrana et al., (2010). They also observed that at low microwave power $(60 \mathrm{~W})$, a good quality of the mushroom was obtained with slow drying rate whereas at high microwave power (240 W) or at atmospheric pressure condition, ineffective drying was observed along with the formation of large voids and the entrapment of moisture inside the sample. Thus, the drying with moderate microwave power at low pressure conditions is recommended for drying mushroom slices.
Wang et al., (2009) dehydrated instant vegetable soup mix in a microwave freeze dryer to study the drying characteristics and sensory properties of the dried product. Vegetable soup was successfully dried in the microwave freeze dryer and microwave power significantly influences the total drying time and sensory quality of final products. High microwave power resulted in shorter drying time but poorer product quality, whereas too low a microwave power leads to excessively long drying time.

The total drying time increased with the increase of material thickness and load, whereas material with too thin layer that causes the product quality to deteriorate. Experimental result also indicates that when the material (450 g) drying at microwave power of $450-675 \mathrm{~W}$, material thickness of $15-20 \mathrm{~mm}$ and temperature between $50-60^{\circ} \mathrm{C}$ could obtain final products with relatively short drying times and acceptable sensory quality.

Yanyang et al., (2004) dehydrated wild cabbage by a combination of hot-air drying and microwave vacuum drying. Its shows that the combination drying involving hot air drying followed by microwave-vacuum drying shortens drying time and also greatly improves the retention of chlorophyll and ascorbic acid in the dried product. Finally they concluded that the microwave drying shows effective bactericidal action in the product with acceptable quality of dried product. Das and Kumar (2013) evaluated the feasibility of microwave enhanced hot air heating system for simultaneous dry blanching and dehydration of mushroom slices. Application of microwave energy at the beginning of dehydration process to inactivate enzymes as well as to remove a certain amount of moisture at the same time and then followed by hot air drying to complete the process. 
Mushroom slices were pre-treated with different microwave power levels of 240,360 and $480 \mathrm{~W}$ for 1,3 and $5 \mathrm{~min}$ before the hot air-drying. The optimum range of the microwave power level and pre-treatment time was found to be $360 \mathrm{~W}$ for $3 \mathrm{~min}$ and $360 \mathrm{~W}$ for $1 \mathrm{~min}$ in obtaining the maximum and minimum levels of response parameters. Shirkole and sutar (2018) carried out finishdrying of commercially available paprika (16.25\% (db) moisture) using microwaves at higher power density (5 to $25 \mathrm{~W} / \mathrm{g}$ ). The acceleration in moisture diffusion and colour degradation during high power short time finish drying of paprika takes place with an increase in the difference between the temperature of paprika and corresponding glass transition temperature. They found that the microwave power above $15 \mathrm{~W} / \mathrm{g}$ dries the paprika beyond monolayer moisture content and leads to accelerated moisture diffusion and colour degradation. Also observed that the high microwave power generates the expanded intercellular spaces in paprika. Deepika and Sutar (2018) dried lemon slices using infrared-microwave hot air combination drying.

They found that the infrared hot air drying effective in pre-treated lemon slices up to 1 hour without entering in drastic falling-rate period. Therefore, after $1 \mathrm{~h}$ microwave hot air was used to complete the drying process. Also, the infrared hot air drying reduces the specific energy consumption compared to conventional drying while maintaining the product quality and microwave hot air drying saves energy and drying time if applied as finish drying for osmotic-infrared hot air dried lemon slices. The quality of the product is also maintained with minimum specific energy consumption in microwave hot air drying due to very short drying time (10.3 min). The optimum infrared drying condition was found at $3000 \mathrm{~W} / \mathrm{m}^{2}$ radiation intensity, $90^{\circ} \mathrm{C}$ air temperature, $100 \mathrm{~mm}$ distance between lamp and product and $1.5 \mathrm{~m} / \mathrm{s}$ air velocity. Whereas in microwave finish drying, the power density of $0.30 \mathrm{~W} / \mathrm{g}, 89.9^{\circ} \mathrm{C}$ air temperature, and $0.5 \mathrm{~m} / \mathrm{s}$ air velocity were reported to result in the best product. It can be observed from various studies reported that microwave power levels have significant effect on the drying time and rate of vegetables and spices. Microwave drying of vegetables and spices and their effects are summarized in Table 2.

\section{Herbs and leaves}

The application of a microwave drying method could offer an alternative way for the herb processing industry. Kathirvel et al., (2006) investigated the efficacy of microwave drying of herbs viz., mint, coriander, dill and parsley leaves at selected levels of microwave power density $(10,30,50,70$ and $90 \mathrm{~W} / \mathrm{g})$ and compared with convection air drying (45, 60 and $75^{\circ} \mathrm{C}$ ).

They found that, as increase in air temperature from 45 to $75^{\circ} \mathrm{C}$ resulted in 77 to $90 \%$ reduction in drying time. The microwave drying technique has more efficient than conventional hot air drying and resulted in savings to an extent of about 95 to $98 \%$ of drying time. The single exponential model used to describe the drying kinetics of leaves gave an excellent fit for all the data points with higher coefficient of determinations. The value of the drying constant increased with the increased microwave output power signifying faster drying of the product.

The microwave dried leaves exhibited less shrinkage and thus had better rehydration characteristics. Dried leaves were safe and stable with respect to microbial growth, biochemical reaction rates and physical properties based on water activity values. Compared to hot air dying, the microwave drying can be effectively used for drying 
herbs (mint, dill, coriander and parsley leaves) owing to improved drying kinetics (sharp reduction of drying time, increased drying rate) and better quality attributes (higher rehydration ratio, ensured economic viability and microbiological safety, retention of colour and chlorophyll content) reported by Kathirvel et al., (2006). Green leafy vegetables (GLVs) are highly perishable but can be preserved by various methods including dehydration which is eco-friendly and easily adoptable. Patil et al., (2015) carried out dehydration of GLVs (fenugreek, coriander, spinach, mint, shepu and curry leaves) and observed its effects on quality. Drying characteristics of GLVs were evaluated at different microwave output powers 135 to $675 \mathrm{~W}$. They found that, as the microwave output power increased from 135 to $675 \mathrm{~W}$, the drying time reduced significantly by $64 \%$.

They also reported that the green leafy vegetables dried at lower power output contain higher amount of nutrition content like protein, calcium and chlorophyll than dried at higher power output. Microwave oven dried green leafy vegetables could be stored for about 21 days in packaging material of metalized polyester, under extreme condition $\left(45^{\circ} \mathrm{C}, 95 \% \mathrm{RH}\right)$.

They also predicted that the shelf life of microwave oven dried green leafy vegetables minimum up to six months if stored in metalized polyester (MP) at $65 \% \mathrm{RH}$ and $30^{\circ} \mathrm{C}$ temperature. Combined microwave and vacuum drying of biomaterials has a good potential for high quality dehydrated products. Mujaffar and Loy (2016) investigated the effect of microwave power level $(200,500,700$ and $1000 \mathrm{~W})$ on the drying behaviour of amaranth leaves. From the results, they concluded that the microwave drying appears to be a feasible drying method for the rapid drying of amaranth leaves.
Microwave power level has a significant impact on the drying rates and quality of dried samples. An increase in power level resulted in more rapid drying, with the risk of burning increasing at $1000 \mathrm{~W}$ power. Drying at $200 \mathrm{~W}$ power level was the least favourable drying treatment in terms of drying rate and overall appearance. They reported optimum power level based on drying rates, quality and appearance of the leaves to be $700 \mathrm{~W}$ with a maximum drying time of $11.5 \mathrm{~min}$ for $20 \mathrm{~g}$ samples. These leaves remained intact as whole leaves but could be easily crushed to flakes or blended to a powder.

Drying at this power level occurred in the falling rate period at moisture values below $4.5 \mathrm{~g} \mathrm{H}_{2} \mathrm{O} / \mathrm{g}$ dry matter, following an initial warm-up period. Jeni et al., (2010) carried out experiments on commercialized biomaterials dryer using a combined unsymmetrical double-feed microwave and vacuum system. Three kilograms of tea leaves were applied with the microwave power of 800 and $1600 \mathrm{~W}$ (single-feed and unsymmetrical double-feed magnetrons respectively) operating at frequency of $2450 \mathrm{MHz}$.

Rotation rates of the rotary drum were fixed at $10 \mathrm{rpm}$. Vacuum pressure was controlled at the constant pressure of 385 Torr and 535 Torr, respectively. Experimental result shows that the high power level and continuous operating mode causes more injury to the structure of tea leaves sample whereas operating with pulse mode at 385 Torr ensured the rapid drying and the best overall quality of dried tea leaves and thus the technique was selected as the most appropriate for tea leaves drying. Also they suggested that the combined microwave and vacuum drying has found some application in the drying of biomaterials, therefore more research and development is needed before the process use to large commercial scale, especially in continuous process. 
Ozkan et al., (2007) dried spinach leaves with sample size $50 \mathrm{~g}$ weight in a microwave oven using eight different microwave power levels ranging between 90 and $1000 \mathrm{~W}$. Drying processes were completed between 290 and 400 s depending on the microwave power level. Energy consumption remained constant within the power range of $350-1000 \mathrm{~W}$, whereas 160 and $90 \mathrm{~W}$ resulted in significant increase in energy consumption. They obtained best quality products in terms of colour and ascorbic acid at $750 \mathrm{~W}$ microwave powers and drying time $350 \mathrm{~s}$ with least energy consumption $(0.12 \mathrm{kWh})$. Fathima et al., (2001) studied the effect of microwave drying and storage on physical and sensory properties of selected green vegetables (coriander, mint, fenugreek, amaranth and shepu). The drying was carried out at $100 \%$ power with the different drying time from 10 to $16 \mathrm{~min}$. They found that microwave drying affected colour, appearance and odour of all the green vegetables. They reported that the process was highly suitable for amaranth and fenugreek, moderately suitable for shepu and less suitable for coriander and mint.

They suggested that drying of the selected greens in a microwave oven is feasible. Storage of the dried greens up to 60 days was also possible with little alteration in sensory attributes. Microwave drying could be a promising preservative technique for greens. Soysal (2004) dried parsley leaves in a domestic microwave oven to determine the effects of microwave output power on drying time, drying rate and colour. They used seven different microwave output powers ranging from 360 to $900 \mathrm{~W}$ for the experiments. Drying took place mainly in constant rate and falling rate periods. After a short heating period a relatively long constant rate period was observed and approximately $40.5 \%$ of the water was removed in this period. Increasing in the microwave output power resulted in a considerable decrease in drying time. No significant differences were observed between the colour parameters of fresh and microwave-dried leaf materials, except for some decrease in whiteness value. The change in colour values was not dependent on the microwave output power.

Although some darkening occurred, microwave drying maintained a good green colour close to that of the original fresh parsley leaves. Therdthai and Zhou (2009) dried mint leaves with microwave vacuum drying $(8.0 \mathrm{~W} / \mathrm{g}, 9.6 \mathrm{~W} / \mathrm{g}$ and $11.2 \mathrm{~W} / \mathrm{g}$ at pressure $13.33 \mathrm{kPa}$ ) and hot air drying $(60 \mathrm{C}$ and $70^{\circ} \mathrm{C}$ ). The microwave-vacuum drying could reduce drying time of mint leaves by 85-90\%, compared with the hot air drying. The effective moisture diffusivity has significantly increased when microwave drying was applied under vacuum condition compared with hot air drying.

For colour, the microwave vacuum dried mint leaves were light green/yellow whereas the hot air dried mint leaves were dark brown. The microwave vacuum dried mint leaves had highly porous microstructure whereas the hot air dried mint leaves had packed microstructure and the rehydration rates of the microwave vacuum dried mint leaves were higher than those of the hot air dried ones. Kapoor and Sutar (2018) carried out finish drying and surface sterilization of bay leaves by microwaves. They operate microwave oven at five different power densities were $32.14,53.57,80.35,107.14$ and $142.85 \mathrm{~W} / \mathrm{g}$ and a constant treatment time was maintained at $150 \mathrm{~s}$. They concluded from the results that high power density short time microwave finish drying turns out to be an effective alternative for drying and surface sterilization of bay leaves with acceptable quality parameters. Some of the important studies on drying of herbs and leaves by microwave energy are also summarized in Table 3. 


\section{Fruits}

Yongsawatdigul and Gunasekaran (1996) investigated that the microwave-vacuum drying as a potential method for cranberries. A laboratory-scale microwave-vacuum oven operating either in continuous or pulsed mode until the final moisture content reached $15 \%$ (wet basis). Two levels of microwave power $(250,500 \mathrm{~W})$ and absolute pressure (5.33, $10.67 \mathrm{kPa}$ ) were applied in continuous mode. Whereas in the pulsed mode, two levels of pressure $(5.33,10.67 \mathrm{kPa})$, two levels of power-on time $(30,60 \mathrm{~s})$ and three levels of power-off time $(60,90,150 \mathrm{~s})$ were used with microwave power $(250 \mathrm{~W})$. They found that the application of pulsed microwave energy has more efficient than continuous application, whereas drying efficiency improved when lower pressure $(5.33 \mathrm{kPa})$ was applied in both cases. Shorter power-on time and longer power-off time provided more favourable drying efficiency in pulsed mode. Power-on time of $30 \mathrm{~s}$ and power-off time of $150 \mathrm{~s}$ was the most suitable for maximum drying efficiency. Maskan (2001) studied the drying characteristics of kiwifruits with hot air, microwave and hot air-microwave drying. $\mathrm{He}$ observed that drying took place in the falling rate drying period regardless of the drying method. Drying rate increased with microwave energy or assisting hot air drying with considerable shortening of the drying time. They observed higher shrinkage of kiwifruits during microwave drying and less shrinkage in hot air-microwave drying and further noted that the microwave dried kiwifruit slices exhibited lower rehydration capacity and faster water absorption rate than the other drying methods studied.

Microwave-assisted hot-air dehydration of apple and mushroom has performed with lowpower microwave energy by Funebo and Ohlsson (1998). The variables for experiments were air velocity, microwave output power and air temperature. The microwave energy was supplied by either microwave applicators with transverse magnetic (TM) modes as dominant modes, or by a multimode cavity microwave oven. The quality parameters like rehydration capacity, bulk density and colour were measured. The low air velocity caused a browning of the products. They were got success in reduce the drying time by a factor of two for apple and a factor of four for mushroom by using microwave-assisted hot-air drying. Rehydration capacity was $20-25 \%$ better for TM applicator-dried apples and mushrooms than for multimode cavity dried ones. Horuz et al., (2017) studied the effect of hybrid (microwave-convectional) and convectional drying on sour cherries. Sour cherries were dried by convectional at 50,60 , and $70^{\circ} \mathrm{C}$ and by hybrid drying at 120,150 , and $180 \mathrm{~W}$ coupled with hot air at 50,60 , and $70^{\circ} \mathrm{C}$.

A digital watt-meter was used to determine energy consumption of the drying systems. They got energy efficiency of hybrid drying technique was higher than convectional drying method and the hybrid drying method allowed reducing the drying time as well as higher quality parameters (Total phenolic content, antioxidant capacity and vitamin C) and rehydration ratio compared to convectional drying. They also reported that the hybrid drying technique can be accepted as an alternative drying technique for sour cherry.

Thin layer microwave drying characteristics of apple were evaluated in a laboratory scale microwave dryer at 200, 400 and600 $\mathrm{W}$ by Zarein et al., (2015) and the experimental data were fitted to nine drying models. The Midilli et al., model best described the drying curve of apple slices. The effective moisture diffusivity was determined by using Fick's second law and the values observed between $3.93 \times 10^{-7}$ and $2.27 \times 10^{-6} \mathrm{~m}^{2} / \mathrm{s}$ for the apple. 
The activation energy for the moisture diffusion was found to be $12.15 \mathrm{~W} / \mathrm{g}$. The highest energy efficiency $(54.34 \%)$ has recorded for the samples dried at $600 \mathrm{~W}$ and lowest $(17.42 \%)$ at $200 \mathrm{~W}$. The values of vitamins (A, C and $\mathrm{E}$ ) and malondialdehyde (MDA) in apricot samples dried with the microwave drier were found to be larger than those in apricot samples dried with infrared and also found that the microwave dryer is more effective than infrared dryer in terms of less losses of vitamins, rate of drying and preservation of original colour of apricots (Karatas and Kamışl1, 2007).Feng and Tang (1998) performed experiment on microwave finish drying of diced apples in a spouted bedto improve heating uniformity. They evaporated moisture of diced apple from $24 \%$ moisture to about $5 \%$ at $70^{\circ} \mathrm{C}$ air temperature using four levels of microwave power density (0 to $6.1 \mathrm{~W} / \mathrm{g}$ ). Temperature uniformity in diced apples has greatly improved with the combination method as compared to that with a stationary bed during microwave drying. They also got products with less discoloration and higher rehydration rates as compared to conventional hot air drying or spouted bed drying. Drying time could be reduced by $80 \%$ in microwave and spouted bed drying compared with spouted bed drying without microwave heating. Maskan (2000) dried banana samples using convection $\left(60^{\circ} \mathrm{C}\right.$ at $1.45 \mathrm{~m} / \mathrm{s})$; microwave $(350,490$ and $700 \mathrm{~W}$ power) and convection followed by microwave (at $350 \mathrm{~W}, 4.3 \mathrm{~mm}$ thick sample) finish drying. Result revealed that the drying of banana slices took place in falling rate drying period with taking the longest time convection drying. Higher drying rates were observed with the higher power level. Microwave finish drying reduced the convection drying time by about $64.3 \%$. A physical model was employed to fit the experimental data and gave good fit for all experimental runs except microwave finish data. Microwave finish dried banana was lighter in colour and had the highest rehydration value. Microwave treatment even at a low microwave power and short time can have major effects on the quality of dried apple slices (Askari et al., 2006). They also reported that the coating, air-drying $\left(70^{\circ} \mathrm{C}\right.$, $1.5 \mathrm{~m} / \mathrm{s})$ and microwave treatment $(300 \mathrm{~W}, 10$ s) resulted in the production of puffed and porous apple slices.

The rehydration capacity of air-dried, freezedried and microwave dried apple slices were $404.6 \%, 484.0 \%$ and $676.0 \%$, respectively. In microwave vacuum drying of model fruit gel (simulated concentrated orange juice), a decrease in the moisture content from $38.4 \%$ to less than $3 \%$ was attained in less than 4 min whereas hot air drying took more than $8 \mathrm{~h}$ to reach $10 \%$ moisture (Drouzas et al., 1999). Venkatachalapathy and Raghavan (1998) dried osmotically dehydrated blueberries (pretreated with ethyloleate and sodium hydroxide) with microwave and microwaveassisted convection and freeze drying. They observed that the microwave application reduced the drying time with good quality berry.

They also concluded that the berries with 3:1 and 4:1 fruit to sugar ratios for osmotic dehydration and with inlet air temperatures of $45^{\circ} \mathrm{Cor} 35^{\circ} \mathrm{C}$, microwave power levels of 0.1 to $0.2 \mathrm{~W} / \mathrm{g}$ can be safely used to produce dried blueberries of a quality almost equal to that of freeze-dried berries. Venkatachalapathy and Raghavan (1999) carried out microwave drying of osmotically dehydrated strawberries at different microwave power levels. Strawberries were pretreated with $2 \%$ ethyl oleate and $0.5 \%$ $\mathrm{NaOH}$ in order to make the skin transparent to moisture diffusion and promote rapid dehydration by osmosis. It was observed that the quality parameters of microwave dried strawberries were equal to or better than freeze dried berries in rehydration. 
The berries are softened during microwave treatment compared to that of freeze dried berries due to greater internal heating. Also, it was observed that the shrinkage ratio (volume at any moisture content to the initial volume) of microwave dried berries increases linearly with moisture ratio.

Alibas (2007) dried pumpkin slices using microwave, air and combined microwave and air drying methods. They were used two different microwave output powers 160 and $350 \mathrm{~W}$ in the microwave drying and for airdrying 50 and $75^{\circ} \mathrm{C}$ air temperature were used with $1 \mathrm{~m} / \mathrm{s}$ fan speed. Drying periods lasted 125-195, 45-90 and 31-51 $\mathrm{min}$ and energy consumption was $0.23-0.34,0.61-0.78$ and 0.29-0.42 kWh for microwave, air and combined microwave-air-drying, respectively. Optimum drying period, colour and energy consumption was obtained when microwave and air-drying was applied simultaneously and the optimum combination level was 350 $\mathrm{W}$ microwave applications at $50^{\circ} \mathrm{C}$. Huang et al., (2011) studied the effects of microwavefreeze drying (MFD), freeze drying (FD), microwave vacuum drying (MVD) and vacuum drying (VD) on re-structured mixed apple chips with potato. Based on experimental tests they reported that the texture and quality of MFD chips are better than those of FD chips and the colour of MFD chips was almost the same as that of FD chips.

MFD requires only about half the time need for freeze drying to the same find moisture content and the rehydration rate of MFD chips was about the same as that of FD products while the water retention of MFD samples was higher. The drying time of MVD was shortened by $95 \%$. Therefore they suggested the MFD and MVD are both desirable processes to produce re-structured mixed chips. MVD is appropriate for large scale production due to its short drying time and low energy consumption. On the other hand, MFD can be applied to manufacture high value up-market mixed chips because it can produce chips with best appearance and higher quality.

Rodriguez et al., (2019) evaluate the effect of solar and microwave drying on raspberries cv. Heritage. Physicochemical parameters and quality properties were found significant effects at the end of the drying by both the methods.

Microwave application significantly reduced the drying time compared to solar drying. Quality properties showed that both drying methods allowed a good preservation of surface colour of dried samples with respect to fresh raspberries. Regarding to hardness, the best texture characteristic was obtained with solar drying. They also concluded that both drying methods resulted in a substantial reduction of the antioxidant capacity. A number of important studies on drying of fruits by microwave energy are also summarized in Table 4.

\section{Granular materials}

The high moisture corn sample was dried with help of laboratory microwave oven by Gunasekaran (1990). The microwave oven was operated in both continuous and pulsed modes at $250 \mathrm{~W}$ of magnetron power setting. In the pulsed mode, two magnetron power-on times of 10 sand $15 \mathrm{~s}$ were used each with different power-off times in the range of $20 \mathrm{~s}$ to $75 \mathrm{~s}$. They observed that the drying was more rapid in the continuous mode than in the pulsed mode. But, the continuous mode required much higher total magnetron poweron times, whereas in the pulsed mode, longer power-on times generally resulted in slightly faster drying; and the power off times did not strongly influence the drying rate. Longer power-on times should be followed by relatively longer power-off times. 
For a given on-time, increase in power-off time helps to decrease the total power-on time required for drying. They also reported that when the microwave oven was operated at 10 $\mathrm{s}$ of power-on and $75 \mathrm{~s}$ of power-off pulsing, it resulted in the lowest total power-on time. Kaasova et al., (2002) studied that the microwave drying of soaked rice and compared with the conventional drying process. Soaked rice was treated in microwave oven at different microwave energy levels (90, 160, 350 and $500 \mathrm{~W}$ ), initial moisture contents $(12,23$ and 30\%), and temperatures.

The maximum value of drying rate for conventional hot air drying is up to 50 times lower than the rate observed for microwave drying. The results showed that microwave treatment did not affect the total content of starch in rice. On the other hand, the damaged starch content in rice kernel increased with absorbed microwave energy and temperature of treatment, mainly for initial moisture content $30 \%$ and drying temperature $100^{\circ} \mathrm{C}$. Amylographic characteristics and water sorption capacity showed only minimum changes resulting from microwave drying of rice for initial moisture content lower than $23 \%$.

Combined microwave-hot air drying is an innovative technique that could dramatically reduce processing times for many foods (Gowen et al., 2006). Combined drying of whole and pre-cooked chickpeas were investigated for three microwave power levels $(210,300,560 \mathrm{~W})$ and three air temperature $\left(23,160,250^{\circ} \mathrm{C}\right)$ settings. They concluded that the combined drying with microwave $(210 \mathrm{~W})$ and air temperature $\left(160^{\circ} \mathrm{C}\right)$ has optimal in terms of drying time, rehydration time, texture and colour. Berteli et al., (2009) compared the drying kinetics of the microwave assisted vacuum process with two other drying processes, one using hot air convection and the other combining microwaves with hot air convection and stated that the drying kinetics were not affected by the vacuum levels. Walde et al., (2002) studied the microwave drying and grinding characteristics of wheat. Wheat samples of approximately $20 \mathrm{~g}$ each were dried in a domestic microwave oven for different time periods ranging from 15 to $150 \mathrm{~s}$ with different moisture contents ranging from 0.11 to $0.23 \mathrm{~kg}$ of water $/ \mathrm{kg}$ of dry weight of solids.

The samples were shows an average moisture loss of $4.4 \times 10^{-4}$ to $10.6 \times 10^{-4} \mathrm{~kg}$ of water $/ \mathrm{kg}$ of dry weight of solids per second. The microwave dried samples for $120 \mathrm{~s}$ were crisp and consumed less energy for grinding compared to the control samples. The same trend was maintained even when the wheat samples were dried in bulk by taking $1 \mathrm{~kg}$ of sample (initial moisture content of 0.11 dry weight basis) and dried for $15 \mathrm{~min}$. They also noted that the microwave drying of wheat samples before grinding helps reduce power consumption in due course in wheat milling industries. They also found that the microwave drying did not change the total protein content, but there were some functional changes in the protein which was evident from the gluten measurements.

Jafari et al., (2017) fabricated laboratory scale continuous-band microwave dryer and used for drying the paddy. The experiments were carried out at 3 microwave powers $(90,270$, and $450 \mathrm{~W}$ ), conveyor speed $0.24 \mathrm{~m} / \mathrm{min}$, and 3 paddy layer thicknesses $(6,12$, and $18 \mathrm{~mm})$. The penetration depth of the waves intothe examined paddy was obtained equal to $12.7 \mathrm{~mm}$ at $25.46 \%$ moisture content (w.b \%). The maximum energy absorption ( $81.46 \%$ ) was obtained at $90 \mathrm{~W}$ power and $18 \mathrm{~mm}$ layer thickness, whereas the minimum energy absorption was obtained equal to $34.90 \%$ at $6 \mathrm{~mm}$ paddy thickness and $270 \mathrm{~W}$ microwave 
power. The results indicated that the maximum energy efficiency, the maximum thermal efficiency, the maximum drying efficiency, the minimum specific energy consumption and the minimum seed breakage percent occurred at $90 \mathrm{~W}$ microwave power and $18 \mathrm{~mm}$ drying thickness. They concluded that the drying thickness of $18 \mathrm{~mm}$ and microwave power of $90 \mathrm{~W}$ was selected as the most appropriate combination for drying paddy using the continuous band microwave dryer. Pande et al., (2012) studied on microwave drying for safe storage and improved nutritional quality of green gram seed. They reported that the microwave heating not only increases the insect mortality but also reduces the moisture content and anti-nutritional factor (phytic acid), while the natural green colour of the seed is not affected much. They also stated that, this study provides a novel and environmentally safe technique and increase in the nutritive quality.

Table.1 Dielectric properties of selected food products at $20^{\circ} \mathrm{C}$

\begin{tabular}{|c|c|c|c|c|}
\hline \multirow[t]{2}{*}{ Food product } & \multicolumn{2}{|c|}{ Dielectric constant } & \multicolumn{2}{|c|}{ Dielectric loss } \\
\hline & $915 \mathrm{MHz}$ & $2450 \mathrm{MHz}$ & $915 \mathrm{MHz}$ & $2450 \mathrm{MHz}$ \\
\hline Apple & 57 & 54 & 8 & 10 \\
\hline Almond & 2.1 & - & 2.6 & - \\
\hline Avocado & 47 & 45 & 16 & 12 \\
\hline Banana & 64 & 60 & 19 & 18 \\
\hline Carrot & 59 & 56 & 18 & 15 \\
\hline Cucumber & 71 & 69 & 11 & 12 \\
\hline Dates & 12 & - & 5.7 & - \\
\hline Grape & 69 & 65 & 15 & 17 \\
\hline Grapefruit & 75 & 73 & 14 & 15 \\
\hline Lemon & 73 & 71 & 15 & 14 \\
\hline Lime & 72 & 70 & 18 & 15 \\
\hline Mango & 64 & 61 & 12 & 14 \\
\hline Onion & 61 & 64 & 12 & 14 \\
\hline Orange & 73 & 69 & 14 & 16 \\
\hline Papaya & 69 & 67 & 10 & 14 \\
\hline Peach & 70 & 67 & 12 & 14 \\
\hline Pear & 67 & 64 & 11 & 13 \\
\hline Potato & 62 & 57 & 22 & 17 \\
\hline Radish & 68 & 67 & 20 & 15 \\
\hline Strawberry & 73 & 71 & 14 & 14 \\
\hline Walnut & 3.2 & - & 6.4 & - \\
\hline
\end{tabular}

(Source: Venkatesh and Raghavan, 2004) 
Table.2 Summary of studies on microwave drying of vegetables and spices

\begin{tabular}{|c|c|c|c|}
\hline Food items & Research activity/ Treatments & $\begin{array}{c}\text { Optimum experimental condition / } \\
\text { Recommendation }\end{array}$ & Reference \\
\hline Garlic slices & $\begin{array}{l}\text { Power level- } 100 \% \text { for } 7 \mathrm{~min}, 50 \% \text { for } 8 \mathrm{~min} \text { and } \\
18 \% \text { for } 20 \mathrm{~min} \text {; Hot-air drying- } 45^{\circ} \mathrm{C}\end{array}$ & $\begin{array}{l}\text { Microwave vacuum dried garlic slices } \\
\text { close to that of freeze-dried product and } \\
\text { much better than hot-air drying }\end{array}$ & Cui et al., (2003) \\
\hline $\begin{array}{l}\text { Button } \\
\text { mushroom }\end{array}$ & $\begin{array}{l}\text { Microwave power- } 115 \text { to } 285 \mathrm{~W} \text {; pressure range } \\
\text { of } 6.5 \text { to } 23.5 \mathrm{kPa} \text { and thickness- } 6 \text { to } 14 \mathrm{~mm}\end{array}$ & $\begin{array}{l}\text { Drying efficiency in microwave- } \\
\text { vacuum drying of button mushroom } \\
\text { ranged between } 20.5 \% \text { and } 38.76 \% \text { at } \\
\text { different levels of process variables. }\end{array}$ & Giri et al., (2014) \\
\hline Potato & Microwave power output- $697.87 \mathrm{~W}$ & Microwave pulse ratio 2.0 with $55^{\circ} \mathrm{C}$ & $\begin{array}{l}\text { Soysal et al., } \\
(2009)\end{array}$ \\
\hline Onion & $\begin{array}{l}\text { Hot air- Air velocity } 0,3 \& 5 \mathrm{~m} / \mathrm{s} \text {; Microwave } \\
\text { drying tunnel- } 400 \times 2850 \mathrm{~mm} \text { with } 7.2 \mathrm{~kW} \\
\text { microwave power }\end{array}$ & $\begin{array}{l}\text { Minimum drying time and maximum } \\
\text { drying rate were observed in microwave } \\
\text { dried onion }\end{array}$ & $\begin{array}{l}\text { Laguerre et al., } \\
\text { (1999) }\end{array}$ \\
\hline Carrot slice & $\begin{array}{l}\text { Microwave power- } 350 \mathrm{~W}, 460 \mathrm{~W} \& 600 \mathrm{~W} \text { and } \\
\text { thickness- } 1 \& 2 \mathrm{~cm}\end{array}$ & $\begin{array}{l}\text { Drying rate increase with decrease } \\
\text { thickness and increase power level }\end{array}$ & $\begin{array}{l}\text { Akal and Kahveci } \\
\text { (2016) }\end{array}$ \\
\hline Edamame & $\begin{array}{l}\text { Microwave power- } 700 \text { to } 4200 \mathrm{~W} \text {; Vacuum- } 95 \\
\mathrm{kPa}\end{array}$ & $\begin{array}{l}\text { Power intensity of } 9.33 \mathrm{~W} / \mathrm{g} \text { at vacuum } \\
\text { pressure of } 95 \mathrm{kPa} \text { (gauge pressure) for } \\
15 \mathrm{~min}\end{array}$ & Hu et al., (2007) \\
\hline Onion slices & $\begin{array}{l}\text { Thickness- } 3 \& 7 \mathrm{~mm} \\
\text { convective drying- } 50,60 \& 70^{\circ} \mathrm{C} \\
\text { Microwave power level- } 68,204 \& 340 \mathrm{~W}\end{array}$ & $\begin{array}{l}\text { Onion slices dried by microwave had } \\
\text { higher hardness, gumminess and } \\
\text { chewiness values }\end{array}$ & $\begin{array}{l}\text { Süfer et al., } \\
(2018)\end{array}$ \\
\hline Potato slice & Microwave power- $700 \mathrm{~W}$ & $\begin{array}{l}\text { Reducing drying duration from } 10 \mathrm{~h} \text { to } \\
10 \mathrm{~min}\end{array}$ & $\begin{array}{l}\text { Bouraoui et al., } \\
(1994)\end{array}$ \\
\hline Garlic cloves & $\begin{array}{l}\text { Hot air microwave- } 40 \mathrm{~W} \text { and } 40,50,60 \& 70^{\circ} \mathrm{C} \\
\text { with air velocity } 1.0 \text { and } 2.0 \mathrm{~m} / \mathrm{s} \text {; } \\
\text { Hot air- } 60 \text { and } 70^{\circ} \mathrm{C} \text { with air velocity } 2.0 \mathrm{~m} / \mathrm{s}\end{array}$ & $\begin{array}{l}\text { Drop in the drying time to an extent of } \\
80-90 \%\end{array}$ & $\begin{array}{l}\text { Sharma and } \\
\text { Prasad (2001) }\end{array}$ \\
\hline Carrot cubes & $\begin{array}{l}\text { Microwave power level- } 0,20 \& 40 \% \\
\text { Air temperature- } 45 \text { and } 60^{\circ} \mathrm{C}\end{array}$ & $\begin{array}{l}\text { Reduce drying time- } 25-90 \% \\
\text { Colour of rehydrated carrot was batter } \\
\text { at lower power level. }\end{array}$ & $\begin{array}{l}\text { Prabhanjan et al., } \\
\text { (1995) }\end{array}$ \\
\hline Potato & $\begin{array}{l}\text { Microwave power- } 90 \text { to } 650 \mathrm{~W} \\
\text { Convective drying- air velocity } 1.5 \mathrm{~m} / \mathrm{s} \text { with } 30 \text {, } \\
40 \text { and } 60^{\circ} \mathrm{C}\end{array}$ & $\begin{array}{l}\text { Microwave dried samples had higher } \\
\text { rehydration potential }\end{array}$ & $\begin{array}{l}\text { Khraisheh et al., } \\
\text { (2001) }\end{array}$ \\
\hline Carrot slice & Effects of microwave vacuum drying & $\begin{array}{l}\text { Less colour deterioration occurred in } \\
\text { microwave-vacuum drying }\end{array}$ & Lin et al., (1998) \\
\hline $\begin{array}{l}\text { American } \\
\text { ginseng roots }\end{array}$ & Hot air and combined microwave-hot air drying & $\begin{array}{l}\text { Microwave power- } 60 \mathrm{~W} \text {; Air velocity- } \\
601 / \mathrm{min} \text { with } 40^{\circ} \mathrm{C}\end{array}$ & $\begin{array}{l}\text { Ren and Chen } \\
(1998)\end{array}$ \\
\hline Mushroom & Microwave power- 60,120 and $240 \mathrm{~W}$ & $\begin{array}{l}\text { Microwave power- } 120 \mathrm{~W} \text { with low } \\
\text { pressure }\end{array}$ & $\begin{array}{l}\text { Lombrana et al., } \\
\text { (2010) }\end{array}$ \\
\hline $\begin{array}{l}\text { Vegetable } \\
\text { soup mix }\end{array}$ & $\begin{array}{l}\text { Microwave power- } 0 \text { to } 2000 \mathrm{~W} \text {; Material } \\
\text { thicknesses- } 5,10,15,20 \& 25 \mathrm{~mm} \text {; Material } \\
\text { loads- } 150,300,450 \& 600 \mathrm{~g} ; \text { Materials } \\
\text { temperature- } 40,50,60 \text {, and } 70^{\circ} \mathrm{C}\end{array}$ & $\begin{array}{l}\text { Material load- } 450 \mathrm{~g} \text {; Microwave } \\
\text { power- } 450 \text { to } 675 \mathrm{~W} \text {; Material } \\
\text { thickness- } 15-20 \mathrm{~mm} \text { with } 50-60^{\circ} \mathrm{C}\end{array}$ & $\begin{array}{l}\text { Wang et al., } \\
(2009)\end{array}$ \\
\hline Wild cabbage & $\begin{array}{l}\text { Microwave power- } 1400 \text { to } 3800 \mathrm{~W} \text { and Vacuum- } \\
2-2.5 \mathrm{kPa}\end{array}$ & $\begin{array}{l}\text { The retention of chlorophyll and } \\
\text { ascorbic acid was significantly } \\
\text { improved }\end{array}$ & $\begin{array}{l}\text { Yanyang et al., } \\
(2004)\end{array}$ \\
\hline $\begin{array}{l}\text { Mushroom } \\
\text { slice }\end{array}$ & $\begin{array}{l}\text { Microwave power- } 240,360 \& 480 \mathrm{~W} \text { with } 1,3 \\
\text { and } 5 \text { min drying time }\end{array}$ & $360 \mathrm{~W}$ for $3 \mathrm{~min}$ and $360 \mathrm{~W}$ for $1 \mathrm{~min}$ & $\begin{array}{l}\text { Das and Kumar } \\
(2013)\end{array}$ \\
\hline Paprika & Microwave power density- 5 to $25 \mathrm{~W} / \mathrm{g}$ & $\begin{array}{l}\text { The high microwave power generates } \\
\text { the expanded intercellular spaces in } \\
\text { paprika. }\end{array}$ & $\begin{array}{l}\text { Shirkole and sutar } \\
\text { (2018) }\end{array}$ \\
\hline Lemon slice & Infrared-microwave hot air combination drying & $\begin{array}{l}\text { Infrared drying- } 3000 \mathrm{~W} / \mathrm{m}^{2} \text { radiation } \\
\text { intensity, } 90^{\circ} \mathrm{C} \text { and } 1.5 \mathrm{~m} / \mathrm{s} \\
\text { Microwave- } 0.30 \mathrm{~W} / \mathrm{g}, 89.9^{\circ} \mathrm{C} \text { and } 0.5 \\
\mathrm{~m} / \mathrm{s}\end{array}$ & $\begin{array}{l}\text { Deepika and Sutar } \\
\text { (2018) }\end{array}$ \\
\hline
\end{tabular}


Table.3 Summary of studies on microwave drying of herbs and leaves

\begin{tabular}{|c|c|c|c|}
\hline $\begin{array}{l}\text { Food } \\
\text { items }\end{array}$ & Research activity/ Treatments & $\begin{array}{c}\text { Optimum experimental } \\
\text { condition / } \\
\text { Recommendation }\end{array}$ & Reference \\
\hline Herbs & $\begin{array}{l}\text { Microwave power density- } 10,30 \text {, } \\
50,70 \& 90 \mathrm{~W} / \mathrm{g} \text { and compared with } \\
\text { convection air drying- } 45,60 \& \\
75^{\circ} \mathrm{C}\end{array}$ & $\begin{array}{l}\text { Drying at } 90 \mathrm{~W} / \mathrm{g} \text { produced } \\
\text { the best brightness, redness } \\
\text { and yellowness parameters }\end{array}$ & $\begin{array}{l}\text { Kathirvel } \\
\text { et al., } \\
(2006)\end{array}$ \\
\hline $\begin{array}{l}\text { Green } \\
\text { leafy } \\
\text { vegetables }\end{array}$ & $\begin{array}{l}\text { Microwave drying }-135,270,405 \text {, } \\
540 \& \& \quad 675 \mathrm{~W} \text {; Storage- } \\
\text { polypropylene polyethylene (PP) } \\
\text { and metalized polyester (MP) }\end{array}$ & $\begin{array}{l}\text { Reduce the drying time } \\
\text { Packaging material- } \\
\text { metalized propylene }\end{array}$ & $\begin{array}{l}\text { Patil et al., } \\
\text { (2015) }\end{array}$ \\
\hline $\begin{array}{l}\text { Amaranth } \\
\text { Leaves }\end{array}$ & $\begin{array}{l}\text { Microwave power- } 200,500,700 \\
\text { and } 1000 \mathrm{~W} \text {, }\end{array}$ & $\begin{array}{l}\text { Microwave Power- } 700 \mathrm{~W} \\
\text { and Drying time- } 11.5 \mathrm{~min}\end{array}$ & $\begin{array}{l}\text { Mujaffar } \\
\text { and Loy } \\
\text { (2016) }\end{array}$ \\
\hline Tea leaves & $\begin{array}{l}\text { Microwave power- } 800 \& 1600 \mathrm{~W} \\
\text { Pressure-385 \& } 535 \text { Torr }\end{array}$ & Pulse mode at 385 Torr & $\begin{array}{l}\text { Jeni et al., } \\
\text { (2010) }\end{array}$ \\
\hline Spinach & $\begin{array}{l}\text { Microwave power level- } 90,160 \text {, } \\
350,650,750,850 \& 1000 \mathrm{~W} .\end{array}$ & $\begin{array}{l}\text { Power- } 750 \mathrm{~W} \text {; Drying time- } \\
350 \mathrm{~s} \text {; Energy consumption- } \\
0.12 \mathrm{kWh}\end{array}$ & $\begin{array}{l}\text { Ozkan et } \\
\text { al., (2007) }\end{array}$ \\
\hline $\begin{array}{l}\text { Green } \\
\text { vegetables }\end{array}$ & $\begin{array}{l}\text { Microwave power- } 100 \% \text { with } \\
\text { Drying time- } 10 \text { to } 16 \mathrm{~min}\end{array}$ & $\begin{array}{l}\text { Microwave drying } \text { was } \\
\text { highly suitable for green } \\
\text { vegetables }\end{array}$ & $\begin{array}{l}\text { Fathima et } \\
\text { al., (2001) }\end{array}$ \\
\hline $\begin{array}{l}\text { Parsley } \\
\text { leaves }\end{array}$ & Microwave power- 360 to $900 \mathrm{~W}$ & $\begin{array}{l}\text { Microwave } \\
\text { technology can greatly } \\
\text { reduce the drying time and } \\
\text { successfully be used to } \\
\text { produce good quality dried } \\
\text { parsley flakes in terms of } \\
\text { colour }\end{array}$ & $\begin{array}{l}\text { Soysal } \\
(2004)\end{array}$ \\
\hline $\begin{array}{l}\text { Mint } \\
\text { leaves }\end{array}$ & $\begin{array}{l}\text { Microwave vacuum drying }(8.0 \mathrm{~W} / \mathrm{g} \text {, } \\
9.6 \mathrm{~W} / \mathrm{g} \& 11.2 \mathrm{~W} / \mathrm{g} \text { at pressure } \\
13.33 \mathrm{kPa}) \text { and hot air drying }(60 \mathrm{C} \\
\left.\& 70^{\circ} \mathrm{C}\right)\end{array}$ & $\begin{array}{l}\text { Colour retention was higher } \\
\text { in microwave vacuum drying } \\
\text { than microwave air drying }\end{array}$ & $\begin{array}{l}\text { Therdthai } \\
\text { and Zhou } \\
\text { (2009) }\end{array}$ \\
\hline $\begin{array}{l}\text { Bay } \\
\text { leaves }\end{array}$ & $\begin{array}{l}\text { Power density- } 32.14,53.57,80.35 \\
107.14 \& 142.85 \mathrm{~W} / \mathrm{g}\end{array}$ & $\begin{array}{l}\text { Short time microwave finish } \\
\text { drying at high power density }\end{array}$ & $\begin{array}{l}\text { Kapoor } \\
\text { and Sutar } \\
\text { (2018) }\end{array}$ \\
\hline
\end{tabular}


Table.4 Summary of studies on microwave drying of fruits

\begin{tabular}{|c|c|c|c|}
\hline Food items & Research activity/ Treatment & $\begin{array}{c}\text { Optimum experimental condition / } \\
\text { Recommendation }\end{array}$ & Reference \\
\hline Cranberry & $\begin{array}{l}\text { Microwave power level }(250,500 \mathrm{~W}) \text {; Pressure } \\
\text { level }(5.33,10.67 \mathrm{kPa}) \text {; Power-on time }(30,60 \\
\text { s) and Power-off time }(60,90,150 \mathrm{~s}) \text {. }\end{array}$ & $\begin{array}{l}\text { Power-on ( } 30 \mathrm{~s}) \text { and -off (150 s) time } \\
\text { at } 250 \mathrm{~W}\end{array}$ & $\begin{array}{l}\text { Yongsawatdigul and } \\
\text { Gunasekaran (1996) }\end{array}$ \\
\hline Kiwifruit slices & $\begin{array}{l}\text { Microwave power- } 210 \mathrm{~W} \text { and drying thickness- } \\
5.03 \pm 0.236 \mathrm{~mm}\end{array}$ & $\begin{array}{l}\text { Higher shrinkage of kiwifruits during } \\
\text { microwave drying and less shrinkage } \\
\text { in hot air-microwave drying }\end{array}$ & Maskan (2001) \\
\hline $\begin{array}{l}\text { Apple and } \\
\text { mushroom }\end{array}$ & Microwave output power- $0.5 \mathrm{~W} / \mathrm{g}$ & $\begin{array}{l}\text { Reduce the drying time by a factor of } \\
\text { two for apple and a factor of four for } \\
\text { mushroom by using microwave- } \\
\text { assisted hot-air drying }\end{array}$ & $\begin{array}{l}\text { Funebo and Ohlsson } \\
\text { (1998) }\end{array}$ \\
\hline Sour cherry & $\begin{array}{l}\text { Convectional drying- } 50,60 \text {, and } 70^{\circ} \mathrm{C} \text {; Hybrid } \\
\text { drying at } 120,150 \& 180 \mathrm{~W} \text { with } 50,60 \text {, and } \\
70^{\circ} \mathrm{C}\end{array}$ & $\begin{array}{l}\text { Hybrid drying method allowed } \\
\text { reducing the drying time as well as } \\
\text { higher quality parameters compared } \\
\text { to Convectional drying }\end{array}$ & Horuz et al., (2017) \\
\hline Apple slices & Microwave power- 200,400 and $600 \mathrm{~W}$ & Microwave power- $600 \mathrm{~W}$ & Zarein et al., (2015) \\
\hline Apricot & Microwave and infrared drying & Microwave drying & $\begin{array}{l}\text { Karatas and Kamışlı } \\
\text { (2007) }\end{array}$ \\
\hline Diced apple & $\begin{array}{l}\text { Microwave power density- } 0 \text { to } 6.1 \mathrm{~W} / \mathrm{g} \text {; Air } \\
\text { temperature- } 70^{\circ} \mathrm{C} \text { and Air velocity- } 1.9 \mathrm{~m} / \mathrm{s}\end{array}$ & $\begin{array}{l}\text { Drying time reduced by } 80 \% \text { in } \\
\text { microwave and spouted bed drying. }\end{array}$ & $\begin{array}{l}\text { Feng and Tang } \\
(1998)\end{array}$ \\
\hline Banana slice & $\begin{array}{l}\text { Convection- } 60^{\circ} \mathrm{C} \text { at } 1.45 \mathrm{~m} / \mathrm{s} \text {; } \\
\text { Microwave power- } 350,490 \& 700 \mathrm{~W} \text { and } \\
\text { convection followed by microwave }(350 \mathrm{~W}, 4.3 \\
\text { mm thickness) finish drying }\end{array}$ & $\begin{array}{l}\text { Microwave power- } 350 \mathrm{~W} ; \text { Air } \\
\text { velocity- } 1.45 \mathrm{~m} / \mathrm{s} \text { and temperature- } \\
60^{\circ} \mathrm{C}\end{array}$ & Maskan (2000) \\
\hline Apple slice & $\begin{array}{l}\text { Effects of combined coating and microwave } \\
\text { assisted hot-air drying }\end{array}$ & $\begin{array}{l}\text { Microwave power- } 300 \mathrm{~W} \text { with } 10 \mathrm{~s} \\
\text { time }\end{array}$ & Askari et al., (2006) \\
\hline $\begin{array}{l}\text { Fruit gel } \\
\text { (Simulated } \\
\text { concentrated } \\
\text { orange juice) }\end{array}$ & $\begin{array}{l}\text { Microwave power- } 800 \& 700 \mathrm{~W} \text { and vacuum- } \\
30 \text { to } 50 \text { mbar; Tunnel dryer- } 60^{\circ} \mathrm{C}, \mathrm{RH}-15 \% \\
\text { and air velocity- } 4.5 \mathrm{~m} / \mathrm{s}\end{array}$ & $\begin{array}{l}\text { Microwave-vacuum dried fruit gel } \\
\text { was significantly lighter in colour } \\
\text { than the microwave-air dried product } \\
\text { at atmospheric pressure }\end{array}$ & $\begin{array}{l}\text { Drouzas et al., } \\
(1999)\end{array}$ \\
\hline Blueberries & $\begin{array}{l}\text { Microwave and microwave-assisted convection } \\
\text { power and freeze drying }\end{array}$ & $\begin{array}{l}\text { Microwave power- } 0.1 \text { to } 0.2 \mathrm{~W} / \mathrm{g} \\
\text { and air temperatures- } 45^{\circ} \mathrm{C} \text { or } 35^{\circ} \mathrm{C}\end{array}$ & $\begin{array}{l}\text { Venkatachalapathy } \\
\text { and Raghavan } \\
\text { (1998) }\end{array}$ \\
\hline Strawberries & $\begin{array}{l}\text { Microwave and microwave-assisted convection } \\
\text { power and freeze drying }\end{array}$ & $\begin{array}{l}\text { Qualities of microwave dried } \\
\text { strawberries were equal to or better } \\
\text { than freeze dried berries. }\end{array}$ & $\begin{array}{l}\text { Venkatachalapathy } \\
\text { and Raghavan } \\
\text { (1999) }\end{array}$ \\
\hline Pumpkin slice & $\begin{array}{l}\text { Microwave power- } 160 \text { and } 350 \mathrm{~W} ; \text { Air } \\
\text { temperature- } 50 \text { and } 75^{\circ} \mathrm{C} \text { and fan speed- } 1 \mathrm{~m} / \mathrm{s}\end{array}$ & Microwave power- $350 \mathrm{~W}$ and $50^{\circ} \mathrm{C}$ & Alibas (2007) \\
\hline $\begin{array}{lr}\text { Mixed } & \text { apple } \\
\text { chips } & \text { with } \\
\text { potato } & \end{array}$ & $\begin{array}{l}\text { Microwave-freeze drying, freeze drying, } \\
\text { microwave vacuum drying and vacuum drying }\end{array}$ & $\begin{array}{l}\text { Microwave power- } 4 \mathrm{~W} / \mathrm{g} \text { and } \\
\text { Vacuum- } 5 \mathrm{kPa} \text {, }\end{array}$ & Huang et al., (2011) \\
\hline Raspberries & $\begin{array}{l}\text { Solar and Microwave drying } \\
\text { Microwave power- } 350 \mathrm{~W} \text { (Power density- } 7.5 \\
\text { W/g) with on/off cycle }\end{array}$ & $\begin{array}{l}\text { Microwave application significantly } \\
\text { reduced the drying time compared } \\
\text { tosolar drying }\end{array}$ & $\begin{array}{l}\text { Rodriguez et al., } \\
(2019)\end{array}$ \\
\hline
\end{tabular}


Table.5 Summary of studies on microwave drying of granular materials

\begin{tabular}{|c|c|c|c|}
\hline Food items & Research activity/ Treatment & $\begin{array}{c}\text { Optimum experimental } \\
\text { condition / Recommendation }\end{array}$ & Reference \\
\hline Corn & $\begin{array}{l}\text { Microwave power- } 250 \mathrm{~W} \text {, power-on } \\
\text { time-10 and } 15 \mathrm{~s} \text {, power-off time } 20 \text { to } 75 \\
\mathrm{~s}\end{array}$ & $\begin{array}{l}\text { Increase in power-off time helps } \\
\text { to decrease the total power-on } \\
\text { time required for drying }\end{array}$ & $\begin{array}{l}\text { Gunasekaran } \\
\text { (1990) }\end{array}$ \\
\hline Rice & $\begin{array}{l}\text { Microwave power output }-90,160,350 \& \\
500 \mathrm{~W} \text {; Final temperature of heated rice } \\
60,80 \& 100^{\circ} \mathrm{C} \text { and Initial moisture- } 12 \text {, } \\
23 \& 30 \%\end{array}$ & $\begin{array}{l}\text { The maximum value of drying } \\
\text { rate for conventional hot air } \\
\text { drying is up to } 50 \text { times lower } \\
\text { than the microwave drying }\end{array}$ & $\begin{array}{l}\text { Kaasova et al., } \\
(2002)\end{array}$ \\
\hline Chickpeas & $\begin{array}{l}\text { Microwave power- } 210,300 \& 560 \mathrm{~W} \text { and } \\
\text { Air temperature- } 23,160 \& 250^{\circ} \mathrm{C}\end{array}$ & $\begin{array}{l}\text { Microwave power- } 210 \mathrm{~W} \text { and } \\
\text { temperature- } 160^{\circ} \mathrm{C}\end{array}$ & $\begin{array}{l}\text { Gowen et al., } \\
(2006)\end{array}$ \\
\hline $\begin{array}{l}\text { Pharmaceutical } \\
\text { granule }\end{array}$ & $\begin{array}{l}\text { Microwave power- } 20 \mathrm{~W} \text { and vacuum } \\
\text { pressure- } 50 \text { and } 75 \mathrm{mbar}\end{array}$ & $\begin{array}{l}\text { Drying kinetics were not affected } \\
\text { by the vacuum levels }\end{array}$ & $\begin{array}{l}\text { Berteli et al., } \\
(2009)\end{array}$ \\
\hline Wheat & $\begin{array}{l}\text { Microwave power- } 700 \mathrm{~W} \text { and drying } \\
\text { time- } 90 \text { to } 150 \mathrm{~s}\end{array}$ & $\begin{array}{l}\text { Microwave dried samples for } 120 \\
\mathrm{~s} \text { were crisp and consumed less } \\
\text { energy for grinding compared to } \\
\text { the control samples }\end{array}$ & $\begin{array}{l}\text { Walde et al., } \\
(2002)\end{array}$ \\
\hline Paddy & $\begin{array}{l}\text { Microwave power- } 90,270 \& 450 \mathrm{~W} \text {; } \\
\text { Conveyor speed } 0.24 \mathrm{~m} / \mathrm{min} \text {, drying } \\
\text { thicknesses- } 6,12 \& 18 \mathrm{~mm}\end{array}$ & $\begin{array}{l}\text { Power of } 90 \mathrm{~W} \text { and thickness of } \\
18 \mathrm{~mm}\end{array}$ & $\begin{array}{l}\text { Jafari } \\
(2017)\end{array}$ \\
\hline $\begin{array}{l}\text { Green } \\
\text { seed }\end{array}$ & $\begin{array}{l}\text { Microwave power: } 180 \text { to } 900 \mathrm{~W} \text { and } \\
\text { treatment duration: } 40 \text { to } 80 \mathrm{~s}\end{array}$ & $\begin{array}{l}\text { Microwave power- } 808 \mathrm{~W} \text { and } \\
\text { time- } 79 \mathrm{~s}\end{array}$ & $\begin{array}{l}\text { Pande et al., } \\
(2012)\end{array}$ \\
\hline Paddy & $\begin{array}{l}\text { Microwave power density- } 0.25,0.50 \text {, } \\
0.75,1.00 \text { and } 1.25 \mathrm{~kW} / \mathrm{kg}\end{array}$ & $\begin{array}{l}\text { Drying rates increases and } \\
\text { crystallinity percentage decreases } \\
\text { with an increase in microwave } \\
\text { power density }\end{array}$ & $\begin{array}{l}\text { Behera and Sutar } \\
(2020)\end{array}$ \\
\hline Corn seed & $\begin{array}{l}\text { Hot air drying- } 40,50 \& 60^{\circ} \mathrm{C} \\
\text { Microwave power- } 0,0.6 \& 1.2 \mathrm{~W} / \mathrm{g}\end{array}$ & $\begin{array}{l}\text { Temperature- } 40^{\circ} \mathrm{C} \text { at a power of } \\
0.6 \mathrm{~W} / \mathrm{g}\end{array}$ & $\begin{array}{l}\text { De Faria et al., } \\
(2020)\end{array}$ \\
\hline
\end{tabular}

Radio Microwave Infrared Visible Ultraviolet X-ray Gamma

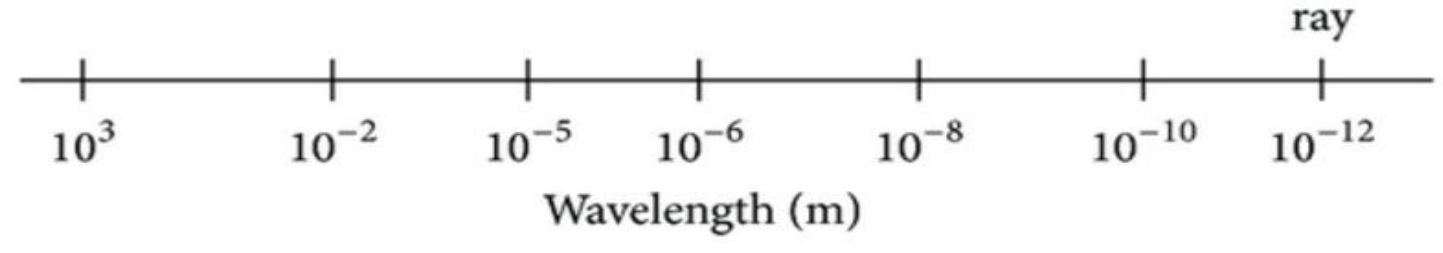

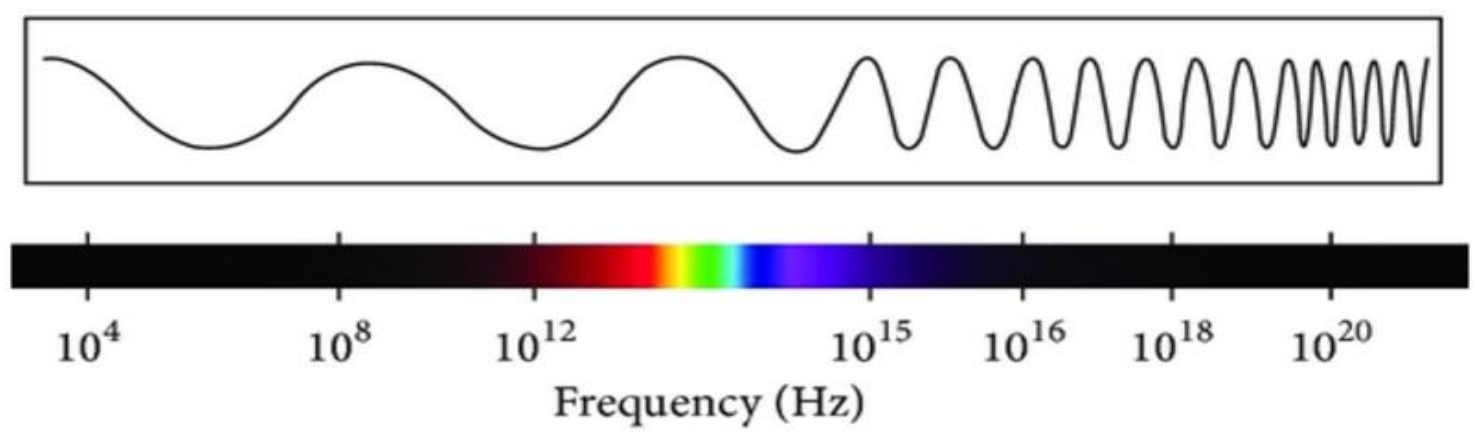

Fig.1 Electromagnetic spectrum 


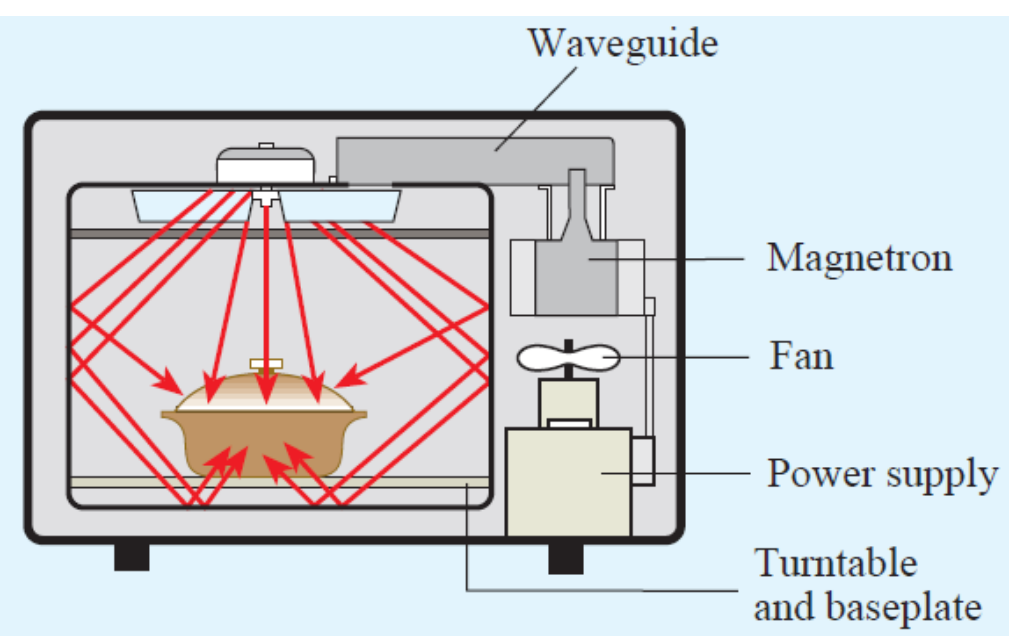

Fig.2 Typical laboratory scale microwave oven

Behera and Sutar (2020) carried out the microwave-assisted starch gelatinization in a semi-pilot microwave rotary drum dryer. The optimized conditions in the starch gelatinization process were found at $1 \mathrm{~kW} / \mathrm{kg}$ power density, $60 \mathrm{~min}$ treatment time, and $90 \mathrm{~mL} / 10 \mathrm{~min}$ water application rate. Microwave power density and treatment time significantly affected the crystallinity percentage and specific energy consumption. Further, the gelatinized paddy was dried in the same dryer at $0.25,0.50,0.75,1.00$, and $1.25 \mathrm{~kW} / \mathrm{kg}$ microwave power density levels. They found that the drying rates increases and crystallinity percentage decreases with an increase in microwave power density. The head rice yield and specific energy consumption were lower in microwave drying compared with hot air drying. At higher power density, the microstructure of starch granules showed formations of internal fissures as well as the effect on the colour and cooking rate constants of the rice.

De Faria et al., (2020) evaluate the effects on the physiological quality of the corn seeds submitted to different drying conditions, using the microwave radiation. The corn seeds with a water content of $20 \%$ on wet basis were dried at 40,50 and $60^{\circ} \mathrm{C}$ and power ratings of $0,0.6$ and $1.2 \mathrm{~W} / \mathrm{g}$; in the vacuum condition. Drying occurred continuously with intermittent power until the products reached the $12 \%$ wet basis. Germination tests accomplished shortly after drying showed that the temperature of $40^{\circ} \mathrm{C}$ at a power of $0.6 \mathrm{~W} / \mathrm{g}$ had a decrease in drying time of around $5 \mathrm{~h}$ when compared to conventional hot air drying $\left(40^{\circ} \mathrm{C}\right.$ and 0.0 $\mathrm{W} / \mathrm{g}$ ). The evaluation of the physiological quality of the seeds showed no significant difference in the germination, vigor and longevity indices of the treated seeds. Microwave drying of several granular food materials and their effect are listed in Table 5.

Microwave drying appears to be a viable drying method for the rapid drying of food materials. The heating and drying of different types of food using microwave increase the economy of time and energy. Microwave power level has a significant impact on the drying rates and quality of dried samples. Energy consumption in microwave drying remained constant within the power intensity range of around 7 to $20 \mathrm{~W} / \mathrm{g}$, whereas at lower power intensity resulted in significant increase in energy consumption. The higher microwave output power considerably lower the drying time. The application of pulsed microwave energy is more efficient than continuous application. The hybrid drying method, especially microwave and hot air, allowed reducing the drying time as well as 
gave the products of higher quality as compared to hot air drying alone. The microwave-vacuum drying could reduce drying time of most vegetable leaves by around $80-90 \%$, compared with the hot air drying.

Microwave drying maintained a good green colour close to that of the original fresh green leaves with surface sterilisation in the vegetables. The grain drying with microwave energy before grinding reduces power consumption in due course in milling industries. The microwave heating of seed not only increases the insect mortality but also reduces the moisture content and antinutritional factor with maintaining the natural green colour of the seed. This study provides a novel and environmentally safe drying technique having a better preservation of the nutritive quality of the final product.

\section{References}

Anonymous (2020) Thinglink, "Electromagnetic Spectrum Diagram", Available at, https://www.thinglink.com/scene/11272 26539860033538, Accessed on April 23, 2020.

Akal D, Kahveci K (2016). Investigation of microwave drying characteristics of carrot slices. In Proceedings of $2^{\text {nd }}$ World Congress on Mechanical, Chemical and Material Engineering (MCM 16) pp. 22-23.

Alibas I (2007). Microwave, air and combined microwave-air drying parameters of pumpkin slices. LWTFood Sci Technol. 40(8): 1445-1451.

Askari GR, Emam-Djomeh Z, Mousavi SM (2006). Effects of combined coating and microwave assisted hot-air drying on the texture, microstructure and rehydration characteristics of apple slices. Food Sci Technol Int. 12(1): 39-46.
Behera G, Sutar PP (2020). Starch gelatinization and drying of paddy using microwave rotary drum dryer: Optimization, kinetics, and cooking studies. Dry Technol. 1-17.

Berteli MN, Rodier E, Marsaioli, JA (2009). Study of the microwave vacuum drying process for a granulated product. Braz J Chem Eng. 26(2): 317-329.

Bouraoui M, Richard P, Durance T (1994). Microwave and convective drying of potato slices. J Food Pro Eng. 17(3): 353-363.

Chandrasekaran S, Ramanathan S, Basak, T (2013). Microwave food processing-A review. Food Res Int. 52(1): 243-261.

Chauhan SK, Sharma CR (1993). Development of instant dehydrated saag. Beverages and Food World. 20(4): 25-26.

Cui ZW, Xu SY, Sun DW (2003). Dehydration of garlic slices by combined microwave-vacuum and air drying. Dry Technol. 21(7): 1173-1184.

Das I, Kumar G (2013). Experimental investigation on simultaneous dry blanching and drying of mushroom slices using microwave enhanced hot air heating system. J Food Sci Eng. 3(10): 517.

De Faria RQ, Dos Santos ARP, Gariepy Y, Da Silva EAA, Sartori MMP, Raghavan V (2020). Optimization of the process of drying of corn seeds with the use of microwaves. Dry Technol. 38(5-6): 676-684.

Deepika S, Sutar PP (2018). Combining osmotic-steam blanching with infraredmicrowave-hot air drying: Production of dried lemon (Citrus limon L.) slices and enzyme inactivation. Dry technol. 36(14): 1719-1737.

Drouzas AE, Tsami E, Saravacos GD (1999). Microwave/vacuum drying of model fruit gels. J Food Eng. 39(2): 117-122.

Fathima A, Begum K, Rajalakshmi D (2001). 
Microwave drying of selected greens and their sensory characteristics. Plant Foods Hum Nutr. 56(4): 303-311.

Feng H, Tang J (1998). Microwave finish drying of diced apples in a spouted bed. J Food Sci. 63(4): 679-683.

Funebo T, Ohlsson T (1998). Microwaveassisted air dehydration of apple and mushroom. J Food Eng. 38(3): 353-367.

Geng YF, Ge XF (2014). The annular microwave dryer design and study on honeysuckle. Advance J Food Sci Tech. 6(3): 395-397.

Giri SK, Sutar PP, Prasad S (2014). Effect of process variables on energy efficiency in microwavevacuum drying of button mushroom. J Food Res Technol. 2(1): 31-38.

Gowen A, Abu-Ghannam N, Frias J, Oliveira J (2006). Optimisation of dehydration and rehydration properties of cooked chickpeas (Cicerarietinum L.) undergoing microwave-hot air combination drying. Trends Food Sci Technol. 17(4): 177-183.

Gunasekaran S (1990). Grain drying using continuous and pulsed microwave energy. Dry Technol. 8(5): 1039-1047.

Hertzendorf MS, Moshy RJ, Seltzer E (1970). Foam drying in food industry. Crit Rev Food SciNutr. 1: 25-70.

Horuz E, Bozkurt H, Karataş H, Maskan M (2017). Effects of hybrid (microwaveconvectional) and convectional drying on drying kinetics, total phenolics, antioxidant capacity, vitamin $\mathrm{C}$, colour and rehydration capacity of sour cherries. Food Chem. 230: 295-305.

Hu QG, Zhang M, Mujumdar AS, Xiao GN, Sun JC (2007). Performance evaluation of vacuum microwave drying of edamame in deep-bed drying. Dry Technol. 25(4): 731-736.

Huang LL, Zhang M, Mujumdar AS, Lim RX. (2011). Comparison of four drying methods for re-structured mixed potato with apple chips. J Food Eng. 103(3): 279-284.

Jafari H, Kalantari D, Azadbakht M (2018). Energy consumption and qualitative evaluation of a continuous band microwave dryer for rice paddy drying. Energy. 142: 647-654.

Jeni K, Yapa M, Rattanadecho P (2010). Design and analysis of the commercialized drier processing using a combined unsymmetrical double-feed microwave and vacuum system (case study: tea leaves). ChemEng Process. 49: 389-395.

Kaasova J, Kadlec P, Bubnik Z, Hubackova B, Prihoda J (2002). Physical and chemical changes during microwave drying of rice. Chemical Papers-slovak Academy of Sciences. 56(1): 32-35.

Kapoor A, Sutar P (2018). Finish drying and surface sterilization of bay leaves by microwaves. In IDS 2018. $21^{\text {st }}$ International Drying Symposium Proceedings Editorial Universitat Politècnica de València. (pp. 18631869).

Karatas F, Kamışlı F (2007). Variations of vitamins (A, C and $\mathrm{E}$ ) and MDA in apricots dried in IR and microwave. $\mathrm{J}$ Food Eng. 78(2): 662-668.

Kathirvel K, Naik KR, Gariepy Y, Orsat V, Raghavan GSV (2006). Microwave drying-a promising alternative for the herb processing industry. In 2006 ASAE Annual Meeting (p. 1).

Khraisheh MAM, McMinn WAM, Magee TRA (2004). Quality and structural changes in starchy foods during microwave and convective drying. Food Res Int. 37(5): 497-503.

Laguerre JC, Tauzin V, Grenier E (1999). Hot air and microwave drying of onions: A comparative study. Drying technology. 17(7-8): 1471-1480.

Lin TM, Durance TD, Scaman CH (1998). Characterization of vacuum microwave, 
air and freeze dried carrot slices. Food Res Int. 31(2): 111-117.

Linn H, Moller M (2003). Microwave heating in Proceedings of the Thermoprocess Symposium, Dusseldorf, Germany pp. 16-21.

Lombrana JI, Rodríguez R, Ruiz U (2010). Microwave-drying of sliced mushroom. Analysis of temperature control and pressure. Innov Food SciEmerg Technol. 11(4): 652-660.

Maskan M (2000). Microwave/air and microwave finish drying of banana. J Food Eng. 44(2): 71-78.

Maskan M (2001). Drying, shrinkage and rehydration characteristics of kiwi fruits during hot air and microwave drying. $\mathbf{J}$ Food Eng. 48(2): 177-182.

Mujaffar S, Loy AL (2016). Drying kinetics of microwave-dried vegetable amaranth (Amaranthus dubius) leaves. J Food Res. 5(6): 33-44.

Mullin J (1995). Microwave processing. In: New Methods of Food Preservation (Gould G W, ed). Blackie Academic and Professional, Bishopbriggs, Glasgow. pp 112-134.

Orsat V, Raghavan V, Meda V (2005). Microwave technology for food processing: an overview. In: The microwave processing of foods, Woodhead Publishing, Cambridge, England. pp. 105-118.

Ozkan IA, Akbudak B, Akbudak N (2007). Microwave drying characteristics of spinach. J Food Eng. 78(2): 577-583.

Pande R, Mishra HN, Singh MN (2012). Microwave drying for safe storage and improved nutritional quality of green gram seed (Vigna radiata). J. Agric. Food Chem. 60(14): 3809-3816.

Patil GD, Pardeshi IL, Shinde KJ (2015). Drying of green leafy vegetables using microwave oven dryer. Journal Ready to Eat Food. 2: 18-26.

Prabhanjan DG, Ramaswamy HS, Raghavan
GSV (1995). Microwave-assisted convective air drying of thin layer. J Food Eng. 25: 283-293.

Ren G, Chen F (1998). Drying of American ginseng (Panaxquin quefolium) roots by microwave-hot air combination. J Food Eng. 35(4): 433-443.

Rodriguez A, Bruno E, Paola C, Campañone L, Mascheroni RH (2019). Experimental study of dehydration processes of raspberries (RubusIdaeus) with microwave and solar drying. Food Sci Technol. 39(2): 336-343.

Sangamithra V, John SG, Kuppuswamy K (2014). Foam mat drying of food materials: a review. J Food Process Pres. 39(6): 3165- 3174.

Schiffmann, R.F. (2006). Microwave and dielectric heating. In handbook of industrial Drying. (Mujumdar, S.A. (Eds)). Third edition, CRC Press, Taylor and Francis Publishers, Oxon, UK, p. 687-709.

Sharma GP, Prasad S (2001). Drying of garlic (Allium sativum) cloves by microwavehot air combination. J Food Eng. 50(2): 99-105.

Shirkole SS, Sutar PP (2019). High power short time microwave finish drying of paprika (Capsicum annuum L.): Development of models for moisture diffusion and colour degradation. Dry Technol. 37(2): 253-267.

Soysal Y (2004). Microwave drying characteristics of parsley. Biosys Eng. 89(2): 167-173.

Soysal Y (2009). Intermittent and continuous microwave-convective air drying of potato (lady rosetta): drying kinetics, energy consumption and product quality. TarımMakinalarıBilimiDergisi. 5(2): 139-148.

Srilakshmi B (2006). Food Science. New Age International Publishers, New Delhi, India.

Süfer Ö, Demir H, Sezer S (2018). 
Convective and microwave drying of onion slices regarding texture attributes. Czech J Food Sci. 36(2): 187-193.

Sutar PP, Prasad S (2008). Microwave drying technology-recent developments and $\mathrm{R} \& \mathrm{D}$ needs in India, in proceedings of the $42^{\text {nd }}$ ISAE Annual Convention, Kolkata, India. pp. 1-3.

Therdthai N, Zhou W (2009). Characterization of microwave vacuum drying and hot air drying of mint leaves (Mentha cordifolia Opiz ex Fresen). J Food Eng. 91(3): 482-489.

Thuery J (1992). Microwaves: Industrial, Scientific and Medical Applications. Artech House, Norwood, MA

Vadivambal R, Jayas DS (2007). Changes in quality of microwave-treated agricultural products-a review. Biosyst Eng. 98: 1-16.

Venkatachalapathy K, Raghavan GSV (1998). Microwave drying of osmotically dehydrated blueberries. J Microwave Power Ee. 33(2): 95-102.

Venkatachalapathy K, Raghavan GSV (1999). Combined osmotic and microwave drying of strawberries. Dry Technol. 17(4-5): 837-853.

Venkatesh MS, Raghavan, GSV (2004). An overview of microwave processing and dielectric properties of agri-food materials. Biosyst Eng. 88(1):1-18.

Vollmer M (2004). Physics of the microwave oven. Physics Education. 39 (1): 74-81

Walde SG, Balaswamy K, Velu V, Rao DG (2002). Microwave drying and grinding characteristics of wheat (Triticum aestivum). J Food Eng. 55(3): 271-276.

Wang R, Zhang M, Mujumdar AS, Sun JC (2009). Microwave freeze-drying characteristics and sensory quality of instant vegetable soup. Dry Technol. 27(9): 962-968.

WoodRuff JG, Luh B (1986). Commercial fruit processing. $2^{\text {nd }}$ edition. AVI Publishers. USA.

Yanyang X, Min Z, Mujumdar AS, Le-qun Z, Jin-cai $S$ (2004). Studies on hot air and microwave vacuum drying of wild cabbage. Dry Technol. 22(9): 22012209.

Yongsawatdigul J, Gunasekaran S (1996). Microwave- vacuum drying of cranberries: Part I. Energy use and efficiency. J Food Process Pres. 20(2): 121-143.

Zarein M, Samadi SH, Ghobadian B (2015). Investigation of microwave dryer effect on energy efficiency during drying of apple slices. J Saudi Soc Agric Sci 14(1): 41-47.

Zhang M, Tang J, Mujumdar AS, Wang S (2006). Trends in microwaverelateddrying of fruits and vegetables. Trends Food Sci Technol. 17: 524-534.

\section{How to cite this article:}

Khodifad, B. C. and Dhamsaniya, N. K. 2020. Drying of Food Materials by Microwave Energy - A Review. Int.J.Curr.Microbiol.App.Sci. 9(05): 1950-1973. doi: https://doi.org/10.20546/ijcmas.2020.905.223 